\title{
Employee Motivation in Vietnamese State-Owned Commercial Banks
}

\author{
Dao Trong Hieu \\ PhD candidate at Graduate Academy of Social Sciences (GASS) \\ E-mail: tronghieu1003@gmail.com \\ Nguyen Hoai Phuong (Corresponding Author) \\ $\mathrm{PhD}$ candidate at Graduate Academy of Social Sciences (GASS) \\ E-mail: phuong.nghoai@gmail.com
}

Received: June 27, 2021 Accepted: July 30, 2021 Published: August 12, 2021

doi:10.5296/bmh.v9i2.18935 URL: https://doi.org/10.5296/bmh.v9i2.18935

\begin{abstract}
Understanding the important of employee motivation in enhancing human resource quality as well as organization effectiveness, Vietnamese State-Owned commercial banks (SOCB) have applied different employee motivational policies. However, these policies haven't been highly effective and effeciency cause of lacking understanding about factors affecting employee motivation. This study aims to identify and measure factors influencing employee motivation in Vietnamese SOCB applied expectancy theory and suggest recommendations to enhance their employee motivation. Data were collected from sending questionnaires to 4 biggest Vietnamese SOCBs. Cronbach's alpha, Exploratory Factor Analysis (EFA), Linear regression were employed for analyzing and processing data. The results show that Expectation (E); Intrinsic rewards (INI); the employee anticipated satisfaction with intrinsic rewards (VI) have positive impact on employee motivation in SOCB. Based on the findings, some recommendations are proposed for SOCBs to improve employee motivations.
\end{abstract}

Keywords: employee motivation, state-owned commercial banks, expectancy theory 


\section{Introduction}

In Vietnam, SOCBs' operation significantly affects the effectiveness of all commercial bank performances. State owned commercial banks (SOCB) account for more than $40 \%$ of market share. The largest bank in terms of total assets, network and still $100 \%$ state owned share is Vietnam Bank for Agriculture and Rural Development (Agribank) and six other SOCBs are Vietnam Joint Stock Commercial Bank for Industry and Trade (Vietinbank), and Joint Stock Commercial Bank for Foreign Trade of Vietnam (Vietcombank), Joint Stock Commercial Bank for Investment and Development of Vietnam (BIDV), Vietnam Construction Bank; Global Petro Commercial Bank, OCEAN Commercial Bank. Until 28/02/2021 total asset of State-Owned commercial banks is $5,845,406$ billion VND, take account $41.55 \%$ of the total credit system asset $(14,065,414$ billion dong), the credit growth is: 0.92 in comparision with $0.33 \%$ of the total system (SBV, (Ivancevich, 1976; Chiang, 2016; Arvey et al., 1973) 2021).

Employee motivation is the willing effort to achieve the organization's goal (Federick, 2008), individual effort employee chooses to join in particular activities (Mitchell, 1984), willingness to exert high levels of effort toward organizational goals, conditioned by the effort's ability to satisfy some individual need (Robbin, 2018). Motivation considerably affects employee performance (Lawler, 1973).

Knowing the employee motivation's significant, SOCBs have implemented a diverse mixture of motivational policies. Nevertheless, these policies haven't been effective and consistent cause of lacking research about factors affecting employee motivation in SOCBs. Besides that, almost research with this topic often applies motivational theory of content process approach, applying a process approach with the believe that greater effort will lead to greater performance (expectancy); good performance will bring desired reward (Instrument) and the employee anticipated satisfaction with this reward (valence) will help SOCBs understand the staff motivation process, thus create policies to enhance their motivation at work.

\section{Theorical Background and Hypothesis}

\subsection{Theorical Background}

Vroom's expectancy theory (1964) explains individual's motivation in order to making decision. According to his study, the three factors that motivate individual to effort in order to achieve his or her purpose, which are expectancy, instrumentality, and valence.

Motivation Force $=$ Expectancy $\mathrm{x}$ Instrumentality $\mathrm{x}$ Valence

Expectancy is the perceived probability that effort will lead to good performance; variables affecting the individual's expectancy perception include self-efficacy, goal difficulty, and perceived control. Expectancy that one's effort will lead to a desired performance is based on past experience, self-confidence, and the perceived difficulty of the performance goal. Instrumentality is the perceived probability that good performance will lead to desired outcomes; trust, control, and polices are variables affecting the individual's instrumentality perception. The instrumentality is the belief that if one does meet performance expectation, he or she will receive a greater reward. Valence refers the value the individual personally places on 
rewards: the function of needs, goals, values and preferences.

In the expectancy theory, the proportional model was used to show the relationship between different components, however, Vroom himself worried about this multiplicative function (Vroom, 1964). Using these VIE components is preferred and more popular than using the initiate models (Ambrose et al., 1999; Julian, 2008; Van Eerde \& Thierry, 1996).

This theory has been applied by many researchers around the world in different focus and context. For example: motivating hotel staff (Chiang, 2006); in the study of entrepreneurs' motivation (Renko et al., 2011); employee motivation to participate in programs of corporate volunteering (De Oliveira et al., 2013); bloggers' work motivation (Liao et al., 2011); teachers' perspectives of motivation and compensation (Soupir-Fremstad, 2013); motivating IT developer (Meymandpour \& Pawar, 2018).

With these literature review above, with the context of SOCBs, research measure the effect of expectancy, rewards (which are instrument) and employee anticipated satisfaction with rewards (which are valences) to employee motivation; classify the reward to intrinsic and extrinsic reward to suggest solutions to improve the SOCB's employee motivation.

\subsection{Hypotheses}

\section{Hypothesis H1: Expectation has a positive effect on employee motivation at SOCBs}

Expectancy is the perceived probability that effort will lead to good performance. Factors that influence perception of expectation include: ablity to achieve the desired outcome on their own, the difficulty level of the goal, and the cognitive control. An individual's effort leading to the desired outcome bases on their past experiences, their confidence and the perceived difficulty of the performance goal (Ivancevich, 1976; Chiang, 2016; Arvey et al., 1973). The higher the expectation is, the higher employee motivation at SOCBs is.

\section{Hypothesis H2: Intrinsic rewards have a positive effect on employee motivation at SOCBs}

Intrinsic rewards are the belief that if employee does meet performance expectations, he or she will receive a greater intrinsic reward - the rewards that related to the nature of the job with includes: recognition/praise by customer at work; personal growth and development; praise when complete the task; recognition/praise from supervisor at work; challenging and interesting work tasks; feeling of accomplishment; responsibility/control over the job (Chiang, 2016; Arvey et al., 1973). The higher "intrinsic rewards" is, the higher "employee motivation" is.

\section{Hypothesis H3: "Extrinsic rewards" have a positive effect on employee motivation at JSCBS}

"Extrinsic rewards" is the belief that if employee does meet performance expectations, he or she will receive a greater extrinsic reward which includes: better relationship with customer, better relationship with colleague; good organization structures and governance; steady and secure employment; good salary/wage; more monetary bonuses (Chiang, 2016; Arvey et al., 1973). There is a positive correlation between "Extrinsic rewards-relationship development" and SOCBs' employee motivation. 
Hypothesis H4: "The anticipated satisfaction of intrinsic rewards" has a positive effect on employee motivation at SOCBs'

"The anticipated satisfaction of intrinsic rewards" is the degree to which the SOCBs' intrinsic rewards satisfy the employee's personal goals or needs and the degree that those potential rewards attract them. The higher degree of this anticipated satisfaction of intrinsic rewards with employee is, the higher "employee motivation" is.

Hypothesis H5: "The anticipated satisfaction of extrinsic rewards" has a positive effect to employee motivation at SOCBs'

"The anticipated satisfaction of extrinsic rewards" is the degree to which the extrinsic rewards of SOCBs' satisfy the personal goals or needs of an employee and the degree that those potential rewards attract them. There is a positive correlation between "the anticipated satisfaction of extrinsic rewards" and "employee motivation".

Based on theorical background and hypotheses design, we have the research model, below:

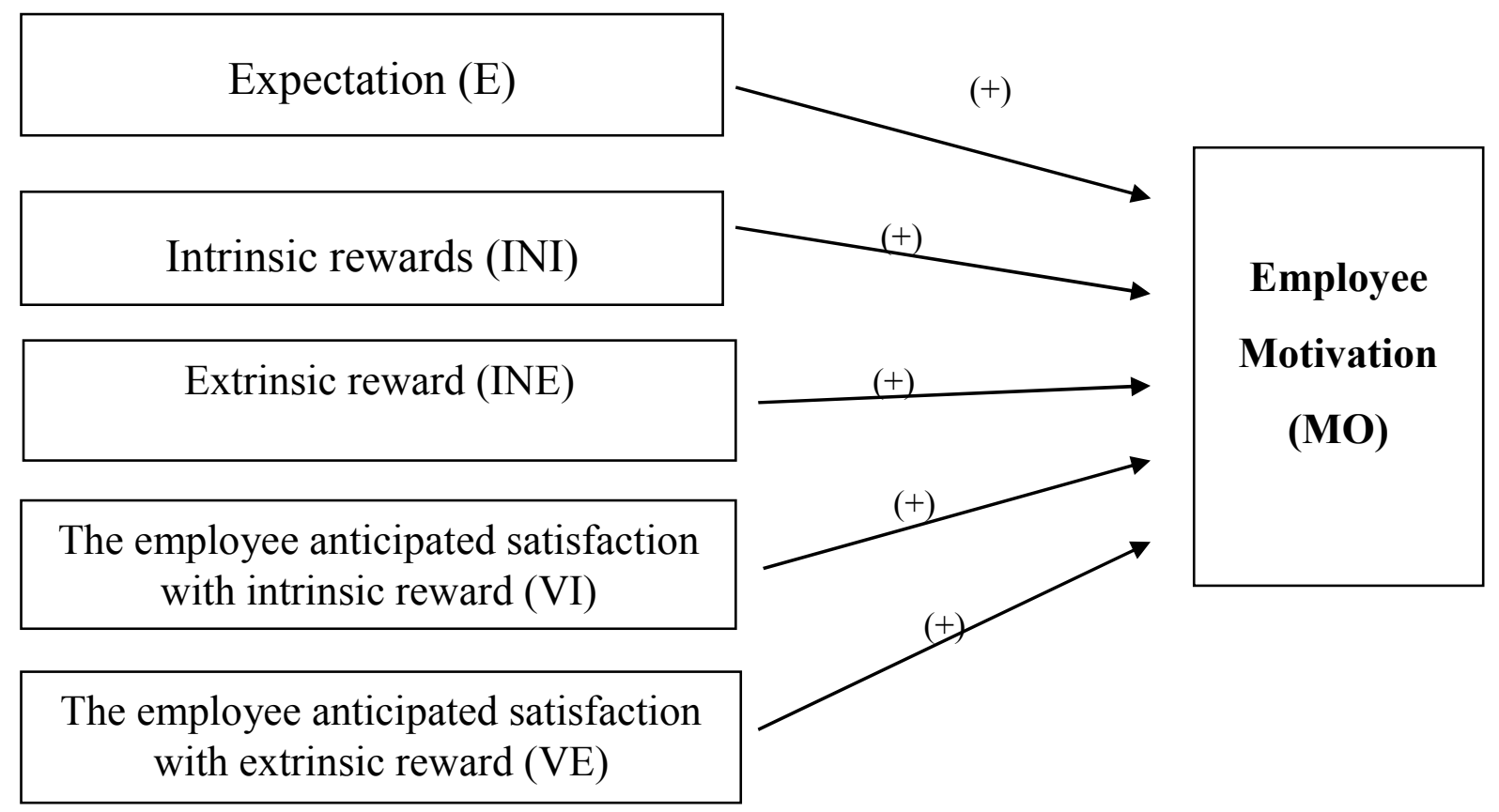

Figure 1. Research model

\section{Research Methodology}

\subsection{Data Collection}

This research used both of quantitative (survey with questionnaire) and qualitative method (collect secondary data). Quasi-random sampling with multistage sampling method was chosen for the questionnaire survey because quasi-random sampling provide a good approximate to random sampling, necessitates the existence of a sampling frame. In our 
survey, we choose 4 SOCBs: Agribank, BIDV, Vietcombank, Viettinbank. In each bank, we chose randomly 4 different branchs.

We sent out 250 questionnaires and received 230 completed responds. The sample size is 230 , met the sampling size requirement of Hair et al. (1998), Tabachnick and Fidell (1996).

Table 1. Sampling statistic description

\begin{tabular}{llll}
\hline \multicolumn{1}{l}{ Factors } & Respondents & Percentage (\%) \\
\hline No & Bank & & \\
$\mathbf{1}$ & Agribank & 97 & 42.2 \\
$\mathbf{2}$ & BIDV & 80 & 34.8 \\
$\mathbf{3}$ & Vietcombank & 28 & 12.2 \\
$\mathbf{4}$ & Viettinbank & 25 & 10.9 \\
Gender & & \\
$\mathbf{1}$ & Female & 147 & 63.9 \\
$\mathbf{2}$ & Male & 83 & 36.1 \\
Age & & & \\
$\mathbf{1}$ & $<25$ & 61 & 26.5 \\
$\mathbf{2}$ & $25-30$ & 92 & 40.0 \\
$\mathbf{3}$ & $30-35$ & 48 & 20.9 \\
$\mathbf{4}$ & $35-40$ & 23 & 10.0 \\
$\mathbf{5}$ & $>40$ & 6 & 2.6 \\
Total & & 230 & 100 \\
\hline
\end{tabular}

In the collected sample, Vietnam Bank for Agriculture and Rural Development (Agribank) has the highest number of responds (97) and the Vietnam Joint Stock Commercial Bank for Industry and Trade (Vietinbank has the lowest number of surveys (19) which consistent with the size of their capital and assets. The gender structure which $63.9 \%$ of respondents is female and the other male is also consistent with the general gender structure of the banking industry which approximate $70 \%$ is female. With the development of the banking sectors in the past 15 years, the average age of banking staff is quite young, thus, the 25-35 age group have the highest percentage while the group higher than 40 is the lowest.

\subsection{Data Analysis}

This research applied SPSS 22 to analyses data collected from quantitative research. Descriptive analyses were used on the six variables in the research. Frequencies were run to determine the number of participants per different demographics. We run reliability analysis, exploratory factor analysis to examine the validity and justification of items used in measurement. Linear Regression analysis was performed to determine the causal relationship among factors affecting and the employee motivation at SOCBs. 


\section{Macrothink}

\section{Empirical Results}

\subsection{Reliability Test}

Firstly, all measurements of key variables are run with reliability test. Variables with values for Cronbach's Alpha $>0.6$ and item-total correlation coefficients of the variables are $>0.3$ are reliable. VE4 item was removed cause of low reliability. Secondly, exploratory factor analysis (EFA) eliminates scales that are not sufficiently reliable, retaining only high degree of adhesion, which can be gathered into factors that accurately reflect the measurement elements of the variables in the model. EFA was conducted twice, specific results are summarized in the following tables. In the first EFA, there are three items INE3, VI3, VE3 that do not guarantee reliability, and are excluded from the study model. The second EFA analysis was conducted, and the results showed that the remaining items were qualified for the next analysis steps: Eigen values (representing the variance explained by each factor) are greater than 1, the cumulative values are greater than $50 \%$, KMO coefficient greater than 0.5 ; Barlett test has a significance level of 0 ( $\mathrm{Sig}<0.05$ ) satisfy the requirements of factor analysis. The "Extrinsic reward" factor separated to 2 different factors: "extrinsic reward-relation and steady job" which measures by 3 items INE1, INE2, INE4 and "extrinsic reward-financial benefit" that includes INE5, INE6. 


\section{IIacrothink}

Business and Management Horizons

ISSN 2326-0297

2021, Vol. 9, No. 2

Table 2. Cronbach alpha analysis results for the first research model

\begin{tabular}{|c|c|c|c|}
\hline Items & Corrected Item-Total Correlation & Cronbach's Alpha if Item Deleted & Cronbach's Alpha \\
\hline 1 & Expectation & & .940 \\
\hline E1 & .987 & & \\
\hline E2 & .833 & & \\
\hline E3 & .830 & & \\
\hline E4 & .805 & & \\
\hline 2 & Extrinsic reward & & 0.833 \\
\hline INE1 & .526 & & \\
\hline INE2 & .667 & & \\
\hline INE3 & .593 & & \\
\hline INE4 & .624 & & \\
\hline INE5 & .605 & & \\
\hline INE6 & .614 & & \\
\hline 3 & Intrinsic reward & & .883 \\
\hline INI1 & .667 & & \\
\hline INI2 & .610 & & \\
\hline INI3 & .698 & & \\
\hline INI4 & .698 & & \\
\hline INI5 & .734 & & \\
\hline INI6 & .689 & & \\
\hline INI7 & .615 & & \\
\hline 4 & The anticipated satisfaction of intrins & ic rewards & .930 \\
\hline VI4 & .708 & & \\
\hline VI5 & .828 & & \\
\hline VI6 & .827 & & \\
\hline VI7 & .796 & & \\
\hline VI1 & .792 & & \\
\hline VI3 & .762 & & \\
\hline VI2 & .721 & & \\
\hline 5 & The anticipated satisfaction of extrin & ic rewards & \\
\hline VE5 & .873 & & \\
\hline VE6 & .888 & & \\
\hline VE1 & .869 & .944 & \\
\hline VE2 & .849 & & \\
\hline VE3 & .758 & & \\
\hline 5 & Employee motivation & & \\
\hline MO1 & .501 & .501 & \\
\hline MO2 & .479 & .479 & \\
\hline MO3 & .594 & .594 & \\
\hline MO4 & .592 & .592 & \\
\hline MO5 & .651 & .651 & \\
\hline MO6 & .690 & .690 & \\
\hline MO7 & .733 & .733 & \\
\hline MO8 & .480 & .480 & \\
\hline
\end{tabular}

Source: Authors' research. 


\section{$1 /$ Macrothink}

Business and Management Horizons ISSN 2326-0297

Table 3. EFA results, Cronbach alpha and mean of independent variables

\begin{tabular}{|c|c|c|c|c|c|c|c|c|}
\hline \multirow[t]{2}{*}{ Item } & \multicolumn{6}{|c|}{ Component } & \multirow{2}{*}{$\begin{array}{l}\text { Cronbach } \\
\text { alpha }\end{array}$} & \multirow[t]{2}{*}{ Mean } \\
\hline & 1 & 2 & 3 & 4 & 5 & 6 & & \\
\hline INI1 & .771 & & & & & & .883 & 3.88 \\
\hline INI3 & .754 & & & & & & & 3.80 \\
\hline INI6 & .736 & & & & & & & 3.79 \\
\hline INI5 & .699 & & & & & & & 3.98 \\
\hline INI4 & .685 & & & & & & & 3.80 \\
\hline INI2 & .636 & & & & & & & 3.80 \\
\hline INI7 & .631 & & & & & & & 3.85 \\
\hline VI6 & & .769 & & & & & .920 & 4.23 \\
\hline VI1 & & .764 & & & & & & 4.21 \\
\hline VI5 & & .748 & & & & & & 4.23 \\
\hline VI7 & & .728 & & & & & & 4.27 \\
\hline VI2 & & .709 & & & & & & 4.31 \\
\hline VI4 & & .658 & & & & & & 4.20 \\
\hline E1 & & & .912 & & & & .940 & 4.23 \\
\hline E4 & & & .848 & & & & & 4.18 \\
\hline E3 & & & .841 & & & & & 4.26 \\
\hline E2 & & & .812 & . & & & & 4.23 \\
\hline VE5 & & & & .857 & & & .946 & 4.35 \\
\hline VE1 & & & & .831 & & & & 4.40 \\
\hline VE6 & & & & .821 & & & & 4.37 \\
\hline VE2 & & & & .785 & & & & 4.36 \\
\hline INE1 & & & & & .843 & & .764 & 4.16 \\
\hline INE2 & & & & & .759 & & & 4.07 \\
\hline INE4 & & & & & .525 & & & 3.90 \\
\hline INE6 & & & & & & .821 & .851 & 3.84 \\
\hline INE5 & & & & & & .801 & & 3.68 \\
\hline $\begin{array}{l}\mathrm{KMO}= \\
\text { Cumul } \\
\text { Bartlet }\end{array}$ & $\begin{array}{l}=75 . \\
\text { of } \mathrm{Spl}\end{array}$ & y: Sig & & & & & & \\
\hline
\end{tabular}

Source: Authors' research. 


\subsection{Adjusted Research Model}

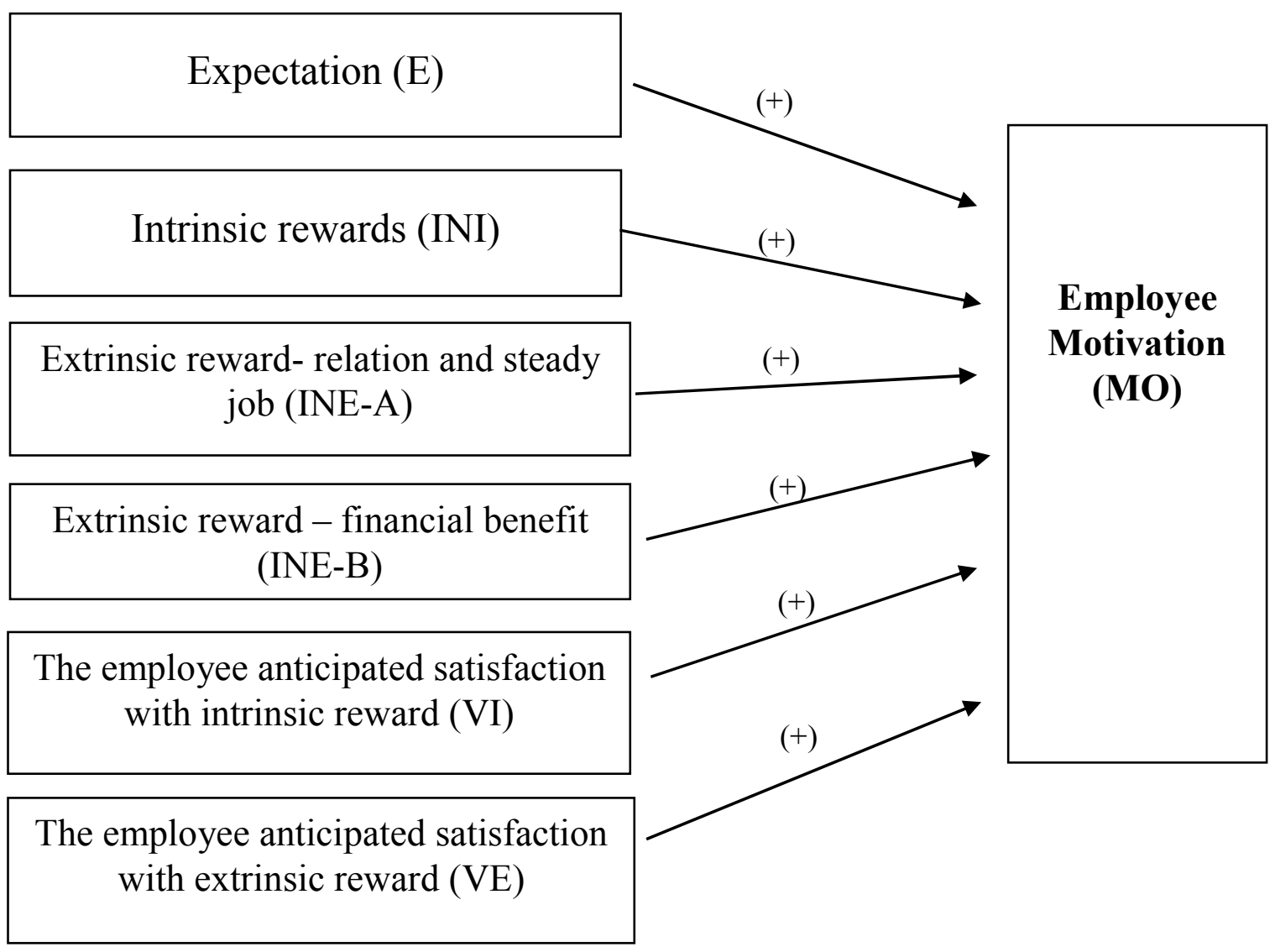

Figure 2. Adjusted research model

\subsection{Adjusted Hypothesis}

Hypothesis H1: Expectation has a positive effect on employee motivation at SOCBs.

Hypothesis H2: Intrinsic rewards have a positive effect on employee motivation at SOCBs.

Hypothesis H3a: "Extrinsic rewards-relation and steady job" have a positive effect on employee motivation at SOCBs.

Hypothesis H3b: "Extrinsic rewards-financial benefit" have a positive effect on employee motivation at JSCBs.

Hypothesis H4: "The anticipated satisfaction of intrinsic rewards" has a positive effect on employee motivation at SOCBs.

Hypothesis H5: "The anticipated satisfaction of extrinsic rewards" has a positive effect to employee motivation at SOCBs. 


\subsection{Test Hypothesis Using Linear Regression}

Table 4. Correlation coefficient

\begin{tabular}{|c|c|c|c|c|c|c|c|}
\hline & & $\mathrm{E}$ & VE & VI & IN & INE-A & INE- B \\
\hline \multirow[t]{3}{*}{$\mathrm{DL}$} & Pearson Correlation & $.544^{* *}$ & $.451^{* *}$ & $.628^{* *}$ & $.633^{* *}$ & $.441^{* *}$ & $.403^{* *}$ \\
\hline & Sig. (2-tailed) & .000 & .000 & .000 & .000 & .000 & .000 \\
\hline & $\mathrm{N}$ & 230 & 230 & 230 & 230 & 230 & 230 \\
\hline
\end{tabular}

Note. ${ }^{* *}$. Correlation is significant at the 0.01 level (2-tailed).

Table 5. Linear regression results

\begin{tabular}{llllll}
\multicolumn{3}{l}{ Model Summary } \\
\hline Model & R & R Square & Adjusted R Square & Std. Error of the Estimate & Durbin-Watson \\
\hline 1 & $.740^{\mathrm{a}}$ & .548 & .536 & .37459 & 1.812 \\
\hline
\end{tabular}

Note. a. Predictors: (Constant), VE, INE67, INE123, E, IN, VI; b. Dependent Variable: DL.

Table 6.

Coefficients $^{\mathrm{a}}$

\begin{tabular}{|c|c|c|c|c|c|c|c|c|}
\hline \multicolumn{2}{|c|}{ Model } & \multirow{2}{*}{\multicolumn{2}{|c|}{$\begin{array}{l}\text { Unstandardized } \\
\text { Coefficients }\end{array}$}} & \multirow{3}{*}{$\begin{array}{l}\text { Standardized } \\
\text { Coefficients } \\
\text { Beta }\end{array}$} & \multirow[t]{3}{*}{$\mathbf{t}$} & \multirow[t]{3}{*}{ Sig. } & \multicolumn{2}{|c|}{ Collinearity Statistics } \\
\hline & & & & & & & & \\
\hline & & B & Std. Error & & & & Tolerance & VIF \\
\hline \multirow[t]{7}{*}{1} & (Constant) & .867 & .203 & & 4.265 & .000 & & \\
\hline & $\mathrm{E}$ & .197 & .045 & 249 & 4.392 & .000 & .925 & 1.081 \\
\hline & IN & .355 & .057 & .389 & 6.198 & .000 & .692 & 1.444 \\
\hline & VI & .275 & .063 & .309 & 4.388 & .000 & .512 & 1.953 \\
\hline & INE- A & -.010 & .049 & -.012 & -.202 & .840 & .820 & 1.219 \\
\hline & INE- B & .002 & .039 & .002 & .040 & .968 & .916 & 1.091 \\
\hline & VE & -.039 & . 049 & -.051 & -.809 & .420 & .668 & 1.495 \\
\hline
\end{tabular}

Note. a. Dependent Variable: DL.

Source: Authors' research.

The results show that the expectation (E), intrinsic reward (INI), the employee anticipated satisfaction with intrinsic reward (VI) have a p-value coefficient smaller than 0.05 , standardized beta is positive, proving that these factors have a positive impact on employee motivational (MO) at the significance level of 0.05 . Looking at the standardized beta coefficient results: intrinsic reward (INI) has the strongest impact on the employee motivation, with the standardized beta of 0.389; descending impact is employee anticipated satisfaction with intrinsic reward (VI-0.309), expectation (E-0.249). 


\section{Macrothink}

Business and Management Horizons

ISSN 2326-0297

2021, Vol. 9, No. 2

The coefficient of determination measures the impact of the independent variables on the dependent variable "employee motivation" is 0.536 , proving that the independent factors in the model can explain $53.6 \%$ of the variation of the "employee motivation" factor in SOCBs. In social science research, especially in the study of factors affecting the dependent variable, the determination which is greater than $50 \%$ is acceptable.

The phenomenon of multi-collinearity results show that there is no multi-collinear phenomenon (tolerance and VIF are satisfied)

Results of hypothesis testing are summarized in Table below:

Table 7. Results of hypothese testing

\begin{tabular}{|c|c|c|}
\hline No. & Hypotheses & Conclusion \\
\hline 1 & H1: "Expectation” has a positive effect on employee motivation at SOCBs & Accepted \\
\hline 2 & H2: "Intrinsic rewards" have a positive effect on employee motivation at SOCBs & Accepted \\
\hline 3 & $\begin{array}{l}\text { H3a: "Extrinsic rewards - relationship and steady job" have a positive effect on employee } \\
\text { motivation at SOCBs }\end{array}$ & Rejected \\
\hline 4 & $\begin{array}{l}\text { H3b: “Extrinsic rewards - financial benefit” have a positive effect on employee motivation } \\
\text { at SOCBs }\end{array}$ & Rejected \\
\hline 5 & $\begin{array}{l}\text { H4: "The anticipated satisfaction of intrinsic rewards" has a positive effect on employee } \\
\text { motivation at SOCBs }\end{array}$ & Accepted \\
\hline 6 & $\begin{array}{l}\text { H5: "The anticipated satisfaction of extrinsic rewards" has a positive effect on employee } \\
\text { motivation at SOCBs }\end{array}$ & Rejected \\
\hline
\end{tabular}

Source: Authors' research.

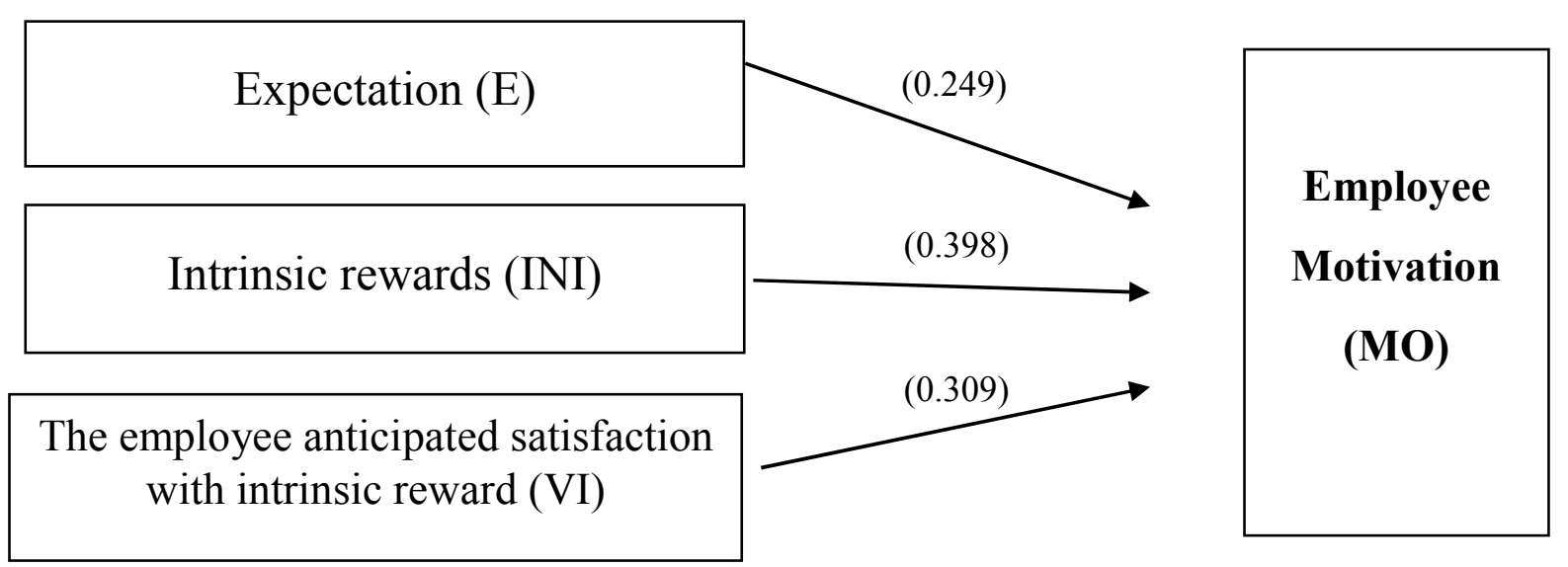

Figured 3. Research results 
4.5 Employee Motivation in SOCBs

Table 8. Employee motivation results.

\begin{tabular}{lllll}
\hline Item & Mean & Median & Mode & Std. Deviation \\
\hline MO8 & 3.79 & 4 & 4 & .856 \\
MO2 & 3.86 & 4 & 4 & .781 \\
MO1 & 3,98 & 4 & 4 & .861 \\
MO4 & 4.00 & 4 & 4 & .823 \\
MO7 & 4.11 & 4 & 4 & .768 \\
MO3 & 4.15 & 4 & 4 & .739 \\
MO5 & 4.16 & 4 & 4 & .725 \\
MO6 & 4.18 & 4 & 4 & .754 \\
Mean & $\mathbf{4 . 0 3}$ & & & \\
\hline
\end{tabular}

Source: Authors' research.

\section{Discussion and Recommendation}

The research results show that the current level of employee motivation in Vietnam SOCB is an average level with an average score of 4.03, equivalent to the response: "agree". The standard deviation is relatively low $(<1)$ which proves that the working motivation of bank staff is quite consistent. The 5 highest score items which mean higher than 4 is MO6 (I often try my best to complete my job even met difficulties), MO5 (I'm ready to work earlier or later to complete my job), MO3 (I take pride in doing my job as well as I can), MO7 (I use my great effort to complete my job to achieve my bank's objectives) and MO4 (I 'm always eager with my job) - these items measure the extrinsic motivation. Whereas MO1 (I often thing how to do the job better), MO2 (I feel down when I do my not well), MO8 (I like to think about the day I do my job well) have the average scores below 4, representing SOCBs employee intrinsic motivation is quite low.

The research also implied that applying expectancy theory in researching employee motivation in SOCBs is significant. The $r$ square is 0.536 means that this model can explain $53.6 \%$ the fluctuation of SOCBs' employee motivation. In social science research, especially in the study of factors affecting the dependent variable, the determination which is greater than $50 \%$ is acceptable because there are many factors that can affect one variable.

The "expectation", "intrinsic reward" and "the anticipated satisfaction of intrinsic rewards" had a positive effect on employee motivation at SOCBs while "extrinsic reward" includes of both "extrinsic reward- relation and steady job" and "extrinsic reward-financial benefit" as well as "the anticipated satisfaction of extrinsic rewards" did not have a statistically significant impact on this. For particularly:

The "Intrinsic rewards" has the strongest impact on employee motivation at SOCB, with a beta coefficient of 0.398 . The expectation of receiving rewards includes: 
responsibility/control over the job, feeling of accomplishment, recognition by customer and colleague at work, praise when complete the task, challenging and interesting work tasks, personal growth and development highly affect the employee motivation. Employees' current belief in achieving these rewards when completing their jobs at SOCBs is at acceptable level, with a mean value of 3.84, shows that motivate employee through these factors at SOCBs are having a positive result. To motivate the employee, SOCBs should increase the employee satisfaction about these rewards, especially enhance the employee belief about the probability of receiving them when complete the job well. The expectation of doing job well will lead to achieve reward will motivate the employee to use more effort to achieve the organization objective. The current employee's satisfaction of these factors arranged descending are: recognition/praise by colleague at work (INI4), personal growth and development (INI1), feeling of accomplishment (INI7), praise when complete the task (INI5), challenging and interesting work tasks (INI3), responsibility/control over the job (INI2), recognition/praise from supervisor at work (INI6). The factor "recognition/praise from supervisor" scored higher than the factor "praise when complete the task" factor; the mean of this factor was also acceptable (greater than 3 and less than 4), demonstrating that encouragement from managers has more positive impact on the staff than the general praise policy of the banks does. If the praise policy is not good or ineffective, SOCBs needs improve this policy. If the policy is good but the implementation is not effective, it is necessary to do internal trainings about praise policies for managers. If both the praise policy and the implementation are good, but the employee's agreement is not high, it is necessary to provide a better communication to make the employees to understand that they are being praised when they perform excellently.

"The anticipated satisfaction of intrinsic rewards" (VI) is the second factor that has a positive impact on the working motivation of the employees at SOCBs which has a beta coefficient of 0.309 . The employee motivations will increase by 0.309 units if the employee anticipated satisfaction of these rewards increase by 1 unit. The level of preference to these rewards is arranged in the following order:); VI4-4.2 (recognition/praise by customer at work); VI1-4.21 (personal growth and development); VI5-4.23 (praise when complete the task); VI6-4.23 (recognition/praise from supervisor at work); VI3-4.26 (challenging and interesting work tasks); VI7-4.31 (feeling of accomplishment); VI2-4.27 (responsibility/control over the job). Thus, SOCBs should attend this sequence when design motivation policy.

The "expectation" is the is the third factor that has a positive impact on the working motivation of the employees at SOCBs which has a beta coefficient of 0.249. When employees' expectation about working hard lead to desired outcomes (enhance the quality of their job performance, improve their productivity significantly, get a lot more accomplished, be regarded by their supervisors as an effective perform) increase by 1 unit, work motivation will increase by 0.249 unit. Factors influence perception of expectation include: ability to achieve the desired outcome on their own, the difficulty level of goals, and cognitive control. An individual's efforts leading to the expected outcomes based on their past experiences, confidence and understandings of the difficulty of an execution goal. This shows that job design and job assignment in accordance with the employee's capacity are extremely important. Building trust in employees about their performance will improve whenever 
efforts are made has a great impact on the work motivation of the employees. Ensuring the conditions of work performance being always supporting employees to perform by their best will enhance their working motivation.

The "Intrinsic rewards" and "The anticipated satisfaction of intrinsic rewards" (VI) has a positive impact on employee motivation while "Extrinsic rewards" and "The anticipated satisfaction of extrinsic rewards" (VE-A and VE-B) did not have a statistically significant impact on this motivation. These results are consistent with the Two factor theory of Heizberg as well as Self-determination theory. Intrinsic motivation coming from the nature of the job affects more strongly and motivation employee in long term better than extrinsic motivation which relate to working environment. The belief of receiving intrinsic reward cause of individual effort and the attractive of them can motivate employee more than their belief and attractive of receiving extrinsic ones.

The rejection of hypothesis $3 \mathrm{a}, 3 \mathrm{~b}$ and 5 shows that the extrinsic reward which employee have been receiving is not affect to their motivation. The explanation for this should be that their expectation about these anticipate receiving reward are much more than they received in real situation, these rewards are not suitable with their used effort.

To enhance the employee motivation, SOCBs manager should:

Maintain the employee believe about greater effort will lead to better performance result by effective job analysis. This can be done through (i) creating specific and clear performance standard for every employee; (ii) planning human resource base on job description, performance standard, job specification, and bank strategic planning, (iii) describing clearly the duties, responsibilities, authorities as well as working condition and working relation, working process in job description, (iv) updating the performance standard regularly.

Make the employee believe about good performance will lead to expected reward. Communicating the human resource policy clearly to ensure every employee understand, receive feedback and negotiate with employee to increase the employee believe in greater effort will lead to achieve rewards.

Implement training and development program. SOCBs' manager should communicate the important of training and development with employee, help employee to develop themselves, improve personal skill and knowledge to complete the job at the moment and in the future, create the development program, career development.

Maintain and implement motivational policies synchronously. Motivation is an individual psychological process, driving force behind all people behavior. To be effective, motivating employee must be a process that comes from the belief that greater effort will lead to greater performance results; good performance will bring desired rewards and these rewards meet the employee need. If the motivational policy is implemented separately, uncontinuously unsynchronized, keep impact on the employee psychology system, their efficiency will not be high. 


\section{Conclusion}

In conclusion, the SOCBs' intrinsic employee motivation is lower than their extrinsic motivation and need to be enhance to improve their performance. The perceived probability that effort will lead to good performance; the belief that if employee does meet performance expectations, he or she will receive a greater intrinsic reward - the rewards that related to the nature of the job with includes: recognition/praise by customer at work; personal growth and development; praise when complete the tasks; recognition/praise from supervisor at work; challenging and interesting work tasks; feeling of accomplishment; responsibility/control over the job; the degree to which the SOCBs' intrinsic rewards satisfy the employee's personal goals or needs explain 53,6\% fluctuation of employee motivation. These results are consistent with the Two factor theory of Heizberg as well as Self-determination theory. Intrinsic motivation coming from the nature of the job affects more strongly and motivation employee in long term better than extrinsic motivation which relate to working environment. The belief of receiving intrinsic reward cause of individual effort and the attractive of them can motivate employee more than their belief and attractive of receiving extrinsic ones. SOCBs' manager can apply these results to create motivational policies more effective and efficiency.

\section{References}

Ambrose, M. L., \& Kulik, C. T. (1999). Old friends, new faces: Motivation research in the 1990s. Journal of Management, 25(3), 231-292. https://doi.org/10.1177/014920639902500302

Arvey, R. D., \& Mussio, S. J. (1973). A test of expectancy theory in a field setting using female clerical employees. Journal of Vocational Behavior, 3, 421-432. https://doi.org/10.1016/0001-8791(73)90054-7

Campbell, J. P., \& Pritchard, R. D. (1976). Motivation theory in industrial and organizational psychology. In M. D. Dunnette \& L. M. Hough (Eds.), Handbook of industrial and organizational psychology (pp. 63-130). New York: Wiley.

Chiang, C. (2016). An expectancy theory model for hotel employee motivation: The moderating role of communication satisfaction. $\mathrm{PhD}$ thesis. Kansas State University.

Chu, H. T., \& Nguyen, M. N. (2008). Research data analysis by SPSS. Vietnam: University of Economics Ho Chi Minh City, Hong Duc Publisher

Federick, H., Bernard, M., \& Babara, B. S. (2008). The motivation of work. USA: Transaction publishers.

Hackman, J. R., \& Lawler, E. E. (1971). Employee reactions to job characteristics. Journal of Applied Psychology Monograph, 55, 259-286. https://doi.org/10.1037/h0031152

Hair, J. F., Jr., Anderson, R. E., Tatham, R. L., \& Black, W. C. (1998). Multivariate data analysis. MA, Boston: Pearson Education Inc.

Ivancevich, J. M. (1976). Expectancy theory predictions and behaviorally anchored scales of 


\section{Macrothink}

Business and Management Horizons

ISSN 2326-0297

2021, Vol. 9, No. 2

motivation: An empirical test of engineers. Journal of Vocational Behavior, 8, 59-75. https://doi.org/10.1016/0001-8791(76)90034-8

Julian, S. D., Ofori Dankwa, J. C., \& Justis, R. T. (2008). Understanding strategic responses to interest group pressures. Strategic Management Journal, 29(9), 963-984. https://doi.org/10.1002/smj.698

Laurie, J. M. (2005). Management and organizational behavior. Canada: Pearson.

Lawler, E. E. (1973). Motivation in Work Organizations. Monterey, CA: Brooks Cole Pub. Co.

Mitchell, T. R. (1984). Expectancy models of job satisfaction, occupational preference and effort: A theoretical, methodological and empirical appraisal. Psychological Bulletin, 81, 1053-1077. https://doi.org/10.1037/h0037495

Steers, R. M., \& Porter, L. W. (1983). Motivation and work behavior. New York: Mc Gorve Hill.

Tabachnik, B. G., \& Fidell, L. S. (1996). Using Multivariate Statistics. New York: HarperCollins College.

Van Eerde, W., \& Thierry, H. (1996). Vroom's expectancy models and work-related criteria: A meta-analysis. Journal of Applied Psychology, 81(5), 575. https://doi.org/10.1037/0021-9010.81.5.575

Vroom, V. H. (1964). Work and motivation. New York: Wiley.

\section{Copyrights}

Copyright for this article is retained by the author(s), with first publication rights granted to the journal.

This is an open-access article distributed under the terms and conditions of the Creative Commons Attribution license (http://creativecommons.org/licenses/by/4.0/). 